\title{
Sınır-Fenomen Olarak Rüyasız Uyku
}

\section{Dreamless Sleep as a Limit-Phenomenon}

\author{
Çağlar Koç ${ }^{1}$ (1)
}

${ }^{1}$ Dr., İstanbul, Türkiye

ORCID: Ç.K. 0000-0002-6733-6620

Sorumlu yazar/Corresponding author: Çağlar Koç,

İstanbul, Türkiye

E-mail/E-posta: caglarkoc80@gmail.com

Başvuru/Submitted: 05.10.2020

Kabul/Accepted: 09.11.2020

\section{Atıf/Citation:}

Koc, Caglar. (2020). "Sınır-Fenomen Olarak Rüyasız Uyku " Felsefe Arkivi-Archives of Philosophy, 53: 25-34. https://doi.org/10.26650/arcp.805534

\section{ÖZET}

Bu yazı rüyasız uykuyu bilincin çeperinde kalan bir fenomen, Edmund Husserl'in deyimiyle deneyimin bir sınır-durumu (Limesfall) olarak ele almaktadır. Fenomenolojik açıdan, rüyasız uyku bize gündelik hayatımıza şekil veren olağan deneyimlere özgü uyanık bilinçliliğin ardına geçmeyi dayatır. Uyurken bilinç asla ortadan kalkmaz. Dolayısıyla ölümden farksız ve bilinçten tamamen yoksun mutlak bir uyku teorik bir kurgudan ibarettir. Yazının birinci bölümünde felsefe tarihi boyunca rüyasız uyku hakkında görüş ileri süren filozoflar üzerinde durulmaktadır. Immanuel Kant'ın tam aksine John Locke rüyasız bir uykuya imkân tanır. Fakat rüyasız uykuyu bilinçsiz bir zihin hali olarak kabul eden Locke'dan farklı olarak felsefede uyuyan zihne bir duyarlık atfeden René Descartes, G.W. Leibniz ve (başlı başına üçüncü bölümü kendisine ayırdığımız) Husserl gibi filozoflar bilincin uykuda hiçbir zaman tamamen ortadan kalkmayacağı tezini destekler. Ne var ki uykudaki zayıf bilinçliliği göz önünde bulundurmayı önleyen engellerin başında bilinci refleksiyonun bir başarısı olarak görmek gelir. Bilinci refleksiyona eşitleyen her yaklaşım uyurken tamamen bilinçsiz olduğumuz inancını destekleyecektir. Bunun sebebi uykuda refleksiyonun mevcut olmamasıdır. Oysa sadece uyanıkken mümkün olan refleksiyon faaliyeti ortadan kalktığında bile bulanık, edilgin ve cılız bir arka plan bilinci varlığına devam eder. Dahası, uyurken uyanabilmenin yegâne koşulu böylesi bir bulanık bilince zaten sahip olmamızdır. Uyanabilmek için bizi dışarıdan etkileyenin öne çıkıp bir fark yaratacak biçimde bilincinde olmak gerekir. Anahtar Kelimeler: Rüyasız uyku, bilinç, refleksiyon, sınır-fenomen, fenomenoloji

\section{ABSTRACT}

This paper considers dreamless sleep as a phenomenon that remains at the margin of consciousness, as a limit-case (Limesfall) of experience, to use Edmund Husserl's expression. From a phenomenological point of view, sleep forces us to go beneath the surface of the awakened experience that shapes our daily lives. Consciousness never disappears during sleep. An absolute sleep, death-like and fully devoid of awareness, is a theoretical fiction. The first section of this paper addresses the work of several philosophers who gave different accounts of dreamless sleep. Contrary to Immanuel Kant, John Locke believed that dreamless sleep is possible. However, 
unlike Locke who considered dreamless sleep as a mental state without consciousness, René Descartes, Gottfried Wilhelm Leibniz and Husserl (for whom the third section is reserved) attributed sensibility to the sleeping mind and defended the thesis that consciousness never disappears during sleep. However, the main obstacle to taking into account the dim awareness pertaining to the sleeping mind is the belief that reflection provides consciousness. Every attempt to identify consciousness with reflection supports the claim that we are totally unconscious during sleep, as reflection is absent while we sleep, and reflection is an activity that requires us to be awake. Nevertheless, even when there is no reflection, an ongoing consciousness continues to function in the background. This dim, passive, and confused awareness is the precondition of waking up from sleep, which occurs owing to something affecting us so much so that it stands out, and it seems that this is the only way to wake up.

Keywords: Dreamless sleep, consciousness, reflection, limit-phenomenon, phenomenology

\section{Giriş}

Uyku ölümün kardeşidir, denir. Sıklıkla ölümü hiç bitmeyecek rüyasız bir uyku olarak tahayyül ederiz. Kendi ölümümüzü deneyimleyemeyiz, bu doğru. Zira ölüm bilincin sona ermesidir. Peki ya rüyasız bir uykunun bu yönden ölümden farksız olduğu da doğru mu? Uyurken içimizde ve dışımızda olup bitenlerin farkında değiliz gibidir. Gibidir, dedik çünkü felsefe tarihi boyunca derin uyuyan bir insanın zihni hakkında farklı görüşler öne sürülmüştür. Fenomenolojik açıdan bakılırsa, rüyasız uyku doğrudan seçik bir deneyime konu olmasa bile bize bir sınır-fenomen olarak belirir. Rüyasız uykunun deneyimlenebilirlikten topyekûn mahrum edilmesini önleyen ve bilincin çeperindeki bir fenomen kabul edilmesine izin veren kendine has bir verilmişliği olduğu ileri sürülebilir. Uykuda bilinç sıfır derecesine doğru yakınsar ama asla tam sıfırlanmaz. Bir sınırfenomen sıfatıyla rüyasız uyku bize gündelik hayatımıza şekil veren olağan deneyimlere özgü uyanık bilinçliliğin ardına geçmeyi, asla bilinçsizliğe eşitlenemez bir bilinçaltına doğru gerilemeyi dayatır. ${ }^{1}$

Rüyayı uykunun vazgeçilmez bir tamamlayıcısı olarak görüp uykuda rüya görmediklerini iddia edenlerin aslında rüyalarını hatırlayamadıklarını savunan Immanuel Kant’a göre, uykuyu ölümden ayırmanın tek yolu zihnin uyurken hayalgücü yardımıyla dışarıdan etki almadan temsil üretme faaliyetini sürdürmesidir. ${ }^{2}$ Peki ama Kant’’n sandığı gibi zihni uykudayken dahi bilinçli sayabilmek için rüyalara ihtiyacımız var mı sahiden? Bilinçliliğimiz temsil üreten bir zihin faaliyetinden mi ileri gelir sadece? Bu yazıda rüyasız uykunun hem mümkün olduğunu hem de asgari bir bilinçlilik ihtiva ettiğini savunacağız. Şu sonuca ulaşacağız: Ölümden farksız ve bilinçten tamamen yoksun mutlak bir uyku teorik bir kurgudan ibarettir. Koma ve genel anestezi vakalarını tartışmalı olduklarından ötürü hariç tutacak olursak, olağan hiçbir uyku durumu bizi tümüyle hiçliğe gömüp hissiz kılmaz.

1 Yazının daha başında "bilinç" ya da "bilinçaltı" gibi temel kavramları belli bir perspektifi benimseyerek kullanmamız okuru endişelendirmesin. Aşağıda bu kavramlar üzerinde daha ayrıntılı tartışmalara yer vereceğiz.

2 Immanuel Kant, Anthropologie in pragmatischer Hinsicht, Stuttgart: Reclam, 1983, 116-117. 


\section{Felsefede rüyasız uyku}

Aristoteles Ruh Üzerine adlı eserinde uyanıklık kadar uykunun da ruhun mevcudiyetini gerektirdiğini belirttiğinde ruhu bilince eşitlemeyi aklından kesinlikle geçirmemişti. ${ }^{3}$ Uyuyan bir varlığı ölüden ayıran tek şey canlı olmasıdı. Bir ölüden farklı olarak canlı (ruh sahibi) bir varlık uykusundan uyanma gücü taşır. Bu sebeple, Aristoteles henüz uyanmasa da uyanma gücü taşımasıyla bir ölüden ayırt edilmesi gerektiğini düşündüğü canlı varlığın uyku durumunu edinildiği halde kullanılmayan bir bilgiye benzetir. Uyku, kullanmamamıza rağmen sahip olduğumuz bir bilgi, uykudan uyanmak ise bu bilgiyi kullanmamız gibidir. ${ }^{4}$ Uyanmanın hesabını vermek için çıktığı yolda uykuyu "uyanmaya gücü yeterlik" diye tanımlamayı teklif eden bu ruh anlayışı kesinlikle bilince öncelik tanımıyordu. Bundan ziyade, uykudan uyanıklığa geçişi salt bir imkânın gerçekleşmesi diye görüyordu. Ruh (can) taşıması uykudayken bir varlığın bilinçsiz olmamasını teminat altına almak şöyle dursun, yalnızca geçici süreyle yitirmiş olduğu bilinçliliğe tekrar kavuşabileceğgi anlamına geliyordu. Peki ama Aristoteles'in dediği gibi uyumak tekrar bilinçli hale gelme imkânından $\mathrm{m} ı$ ibarettir?

René Descartes bu soruya hayır cevabını verir. ${ }^{5}$ Descartes bilinci düşünmeye eşitler ve ruhun daima bilinçli olduğunu, yani düşündügünü ileri sürer. Descartes’e göre, bilincin olmadığı yerde ruh ortadan kalkar. ${ }^{6} \mathrm{O}$ halde rüyasız uyku durumunda bile bir kesinti yoktur; uyurken bilinçli olmayı sürdürürüz. Fakat rüyasız bir uykudayken bilinç bedene bağımlı beyin süreçlerinin katkısına borçlu olduğumuz hafızadan mahrum kalıp bedenden bağımsız saf bir zihin faaliyeti gerçekleştirir. Beyinde iz bırakması böylece önlenen düşünceler uykudaki bilinçliliğimizi meydana getirdiğinden Descartes bu bilinçliliği ne uyurken ne de uyandığımızda hatırlayabildiğimizi belirtir. ${ }^{7}$ Gelgelelim eleştirel bir gözle baktığımızda hemen fark ederiz ki geçmişini muhafaza etmesi yoluyla kazanacağı zamansal bir yayılım olmadan gerçekleşen bir düşünce, bilincinde olunanın kendini geçmişten şimdiye sürdürmesine izin vermeyen bir zihin faaliyeti son derece istikrarsız bir bilinçlilik anlayışını temel alır. Nitekim burada olsa olsa anlık, süreksiz ve kaotik bilinç kırıntıları söz konusudur.

Descartes'ın tersine, John Locke zihnin daima bilinçli olduğu (ruhun daima düşündüğü) savını reddeder. Locke'a göre bilinç zihnin kendi işlemleri üzerine dikkat yönelten bir refleksiyon gerçekleştirmesiyle ortaya çıkar. ${ }^{8}$ Ancak ve ancak kendi işlemlerini dikkatle algılayan zihne bilinçli denebilir. Örneğin, Locke çocuklukta algının tamamen dış nesnelere odaklandığını ileri sürerek çocukların kendi zihin işlemlerini henüz refleksiyon yoluyla birer iç nesne olarak algılayamadığını savunur.9 Locke’un dar bilinç tanımı açısından çocukların zihinlerine dolaysız bir bilinç atfetmek

3 Aristoteles, Ruh Üzerine, 412a22.

4 Aristoteles, Ruh Üzerine, 412a23-24.

5 Yaptığımız Descartes atıflarının Descartes' in Charles Adam ve Paul Tannery tarafından hazırlanan toplu eserlerindeki cilt ve sayfa numaraları parantez içinde verilecektir.

6 René Descartes, Méditations métaphysiques. Objections et réponses suivies de quatres lettres, Paris: Flammarion, 1992, 77 (AT IX 21)

7 a.g.e., 390 (AT VII 356-357)

8 John Locke, An Essay concerning Human Understanding, ed. Roger Woolhouse, London: Penguin Books, $2004,118$.

9 a.g.e., 112. 
güç görünmektedir; çocuklar bilinçli olmayı zamanla öğrenir. Locke’un gözünde zihnin bilinçli olmaya bazı durumlarda tümüyle ara verdiğini net biçimde ortaya koyan daha ikna edici bir örnek rüyasız uykudur. Bir çocuk dış nesneleri algılarken algılama işleminin kendisine dikkat etmediği ve zihninde olup bitenleri algılamaktansa dış nesnelere kapılıp gittiği için belli ölçüde "bilinçsiz" diye nitelenebileceği doğruysa da Locke "uyanık" olan her insanın öyle ya da böyle bir dereceye kadar bilinçli olduğu, birtakım düşüncelere sahip olduğu kanısındadır. Bu sebeple, zihnin gerçek anlamda bilinçsiz hale geldiği durum rüyasız uykudur. Locke’a göre rüya görmediğimiz bir uykuda sadece dış algı, hafıza ve hayalgücü devre dışı kalmakla kalmaz, zihnin kendisini nesne kılmaya yarayacak bir refleksiyon da namevcuttur.

Görüleceği gibi, Locke "zihnin bilinçli olması" ile "ruhun düşünmesi” ifadeleri arasında bir özdeşlik kabul eder ve verdiği dar bilinç tanımı çerçevesinde bilinçli olmayan düşüncelerin varlığını kesinlikle kabul etmez. ${ }^{10}$ Locke ruhun daima düşündüğü görüşüne katılmamasına rağmen, düşündüğü her vakit bilinçli bir zihin durumu içinde olduğunu öne sürer. Bu demektir ki düşünme işleminin gerçekleşmesi bu işleme dikkatini odaklayıp onu nesne haline getiren bir refleksiyon olmaksızın imkansızdır. Locke uyanıkken yapıp ettiklerimize bilinç atfetmeye izin verenin onlara eşlik eden böylesi bir refleksiyon olduğunu düşünür. Keza rüyasız uykudayken kendimize bilinç atfedemiyorsak bunun sebebi refleksiyonun yokluğudur. Gelgelelim Locke bilinci sadece düşünmenin değil, zamansal ardışıklık ve sürenin de koşulu olarak gördüğünden, rüyasız uykuyla bölünen iki uyanıklık periyodunun arasındaki zaman akışının nasıl deneyimlendiğini izah etmekte zorlanır. Nitekim Locke'a göre uykuda geçen süre duyumsanmaz. Bu konuda söylemeye iznimiz olan tek şey iki uyanıklık periyodundan ikincisinin ilkini devam ettirdiğidir. Başka bir deyişle, uyandığımızda uzun mu yoksa kısa mı uyuduğumuza dair herhangi bir hisse sahip olmamız imkansızdır. ${ }^{11}$

G.W. Leibniz Locke'un eleştirileri karşısında Kartezyen "ruh daima düşünür” tezini kurtarmaya çalışır. ${ }^{12}$ Bunu yaparken Locke’un bilinci refleksiyona indirgeyen dar bilinç tanımını kabul etmekle birlikte Locke'tan farklı olarak her düşüncenin bilinçli olduğu görüşünü geri çevirir. Locke’a göre zihin bazen hiçbir işlem gerçekleştirmez ve durağan haldedir ama ne zaman bir işlem gerçekleştirse bilinçli olmak zorundadır. Oysa Leibniz için zihin hep fiil halindedir ve zihnin faal olmaya ara vermesi düşünülemez; öte yandan, zihnin gerçekleştirdiği her işleme o işlemi nesneleştirip dikkatimizin odağına yerleştiren bir refleksiyonun eşlik etmesine gerek yoktur. İşte bu sebeple Leibniz herhangi bir refleksiyonun onlara eşlik etmemesi anlamında bazı

10 Locke kişisel özdeşliği bilinçli deneyimlerin meydana getirdiğini düşündüğünden, bilincinde olunmayan düşüncelerin varlığını kabul etseydik dahi onların bizim düşüncelerimiz olmayacağını, bize bir başkasının düşünceleri kadar yabancı kalacaklarını belirtir. Bkz. a.g.e., 114.

11 a.g.e., 175-176.

12 Yaptığımız Leibniz atıflarının Leibniz' in Carl Immanuel Gerhardt tarafından hazırlanan toplu felsefi eserlerindeki cilt ve sayfa numaraları parantez içinde verilecektir. 
zihin işlemlerinin "bilinçdışı" gerçekleştiğini belirtir. ${ }^{13}$ Fakat her ne kadar bilinçdışı diye nitelese de Leibniz bu zihin işlemlerinin ruhun yaşamının her anını bir öncekinden farklılaştırdığına ve zihni yönlendirdiğine inanır. ${ }^{14}$ Ruhtaki değişimler seçik bir algının (refleksiyonun) nesneleri olmamalarına rağmen, sayısız duyusal izlenimin, Leibniz'in tabiriyle birbirlerinden ayırt edilemeyen "minik algıların" toplam etkisi olarak "bulanık biçimde" hissedilir. ${ }^{15}$ Minik algılar her ne kadar bizi etkilese de bu etkilenim dikkatimizi çekecek derecede kuvvetli değildir. Leibniz için zihin biz uyurken de faaldir ve bu durum rüya görmemizden kaynaklanmaz. Rüyasız bir uykuda dahi zihin duyusal izlenimlerden mahrum kalmaz: "Asla zayıf ve bulanık bir his taşımayacak denli derin uyumayız." ${ }^{16}$ Dahası, başlangıcına dair minik bir algımızın mevcut olmadığı hiçbir gürültünün, ne denli büyük olursa olsun, bizi uyandırmasına imkân yoktur. Başka bir deyişle, eğer uyku süresince zihnimiz sürekli etkilenmeseydi, asla uyanamazdık. Zira bizi uyandıracak denli büyük bir algı hiçten ortaya çıkmaz; aksine, kendisinden derece itibarıla ayrılan minik algiları varsayar.

Leibniz belli bir nesneye dikkat etmemeyi uyanık hayatımızda vuku bulan mecazi anlamdaki kısmi bir uyku hali diye ele alırken, gerçek anlamdaki genel uykuyu tüm nesneler karşısında dikkatin ortadan kalması diye tarif eder. ${ }^{17}$ Hatırlatalım ki Leibniz dikkat ve refleksiyonu bilince sahip olmak için zorunlu gördüğünden, uykudaki zihin işlemlerine bilinçdışı gözüyle bakar. Fakat gene de Leibniz'in uykuda iş başında olan refleksiyon-öncesi ve dikkat-öncesi bir bilinçlilik türünü ilk kavramlaştıran düşünürlerden biri olduğunu söylemek bize göre pek yanlış olmayacaktır. Zira Leibniz minik algıların zihni "etkilediğini” ve “yönlendirdiğini” ısrarla belirtir. Leibniz' in geliştirdiği panpsişik felsefe sisteminden bağımsız değerlendirildiğinde, "bilinçsiz bir etkilenme” ifadesinin çelişik terimlere sahip gözükeceğini itiraf etmek zorundayız. Bu sebeple, Leibniz' in "bilinçaltı" kabul ettiği zihin işlemlerinin "bilinçsiz" olduğunu ilan etmekten özenle sakınmak gerekir. ${ }^{18}$

\section{Sınırdaki uyku bilinci}

Uyku bilincin sınırında durur. Bir yandan deneyime mola verdiğimiz, öte yandan bilincin tamamen hiçe indirgenmediği bir günlük zaman aralığıdır. Eğer uykuda bilinçli olmaya son verseydik, nasıl uyanabilirdik? Bir şeyin bizi uykudan uyandırabilmesi için üzerimizde bir etkisinin olması, bununla aynı anlama gelmek üzere, üzerimizdeki etkisinin bilinçli olması

13 Leibniz bizzat "bilinçdışı" (inconscient) sözcüğünü kullanmaz. Bunun yerine "fark edilmeyen" (dont on ne s'aperçoit pas) veya "hissedilmez" (insensible) vb. nitelemelere başvurur. Gelgelelim Leibniz "hissetme" (sentir) ve "his" (sentiment) sözcüklerini "hissedilmez" diye nitelenmesi icap eden duyusal izlenimlerin zihne yaptıkları etkiyi tarif ederken de kullanır. Bu sebeple "hissedilmez" sıfatının refleksiyon-öncesi ve dikkat-öncesi zihin işlemlerine ait olmadığını düşünüyoruz.

14 G.W. Leibniz, Nouveaux essais sur l'entendement humain, Paris: Flammarion, 1990, 42-43. (G5 48)

15 a.g.e., 41. (G5 46-47)

16 a.g.e., 42. (G5 47)

17 a.g.e., 91. (G5 105)

18 Burada Leibniz metinlerini ayrıntılı biçimde değerlendirmek niyetinde değiliz; sadece konumuzu ilgilendiren genel tespitlerle yetiniyoruz. 
gerekir. Zira etkilenebilmek hissetmektir. ${ }^{19}$ Demek ki uyurken bir şekilde duyumsamaya devam ediyor olmalıyız ki uyanma imkanına sahip olalım. Uyurken etkilenebilmek Aristoteles’ in sandığı gibi, bir imkânın edimselleşmesinden ibaret değildir. Uykuda fiilen bilinç iş başında olmalıdır ki uyuyana etkiyen şey duyumsansın. Fiilen bilinçli olduğumuz için etkilenebiliyoruzdur. Yoksa bir etki bizi mucizevi bir şekilde bilinçsizlik halinden bilinç haline taşımıyordur.

Merleau-Ponty'nin belirttiği üzere, uyku sırasında dünyadan uzaklaşıp varoluşumuzun kaynaklarına döneriz ama bu uzaklaşma ve dönüş hala dünyayla dirsek teması halinde gerçekleşir. ${ }^{20}$ Uyurken uyanık hayatımıza şekil veren ilgilerimizin ve meşguliyetlerimizin büyük çoğunluğunun sesi kesilse de uyuyan kişi asla bütün ilgilerine sağır ve bütün hassasiyetlerinden azade değildir. Bir annenin ağlayan bebeği dışında her gürültüde uyuyabilmesine rağmen bebeği ağlar ağlamaz derhal uyanması bunun tipik bir örneğidir. ${ }^{21}$ Keza çoğu insan uyanmak için alarmı ayarladığı vaktin gelmesinden az önce kendiliğinden uyanır. ${ }^{22}$ Leibniz zihnin uykuda asla mutlak bir durgunluğa gömülmediğini vurgulamakta haklıdır. Fenomenoloji geleneğinde Ben’in katıldığı bilinç ile katılmadığı bilinç arasında bir ayrım gözetilir. Uyurken Ben (ego) her ne kadar tam anlamıyla etkin bir faaliyet gerçekleştirmese de bilincin edilgin işlerliği sürer. Bu bakımdan Edmund Husserl gibi fenomenologların edilginliğe etkinliğin en aşağı derecedeki formu gözüyle baktığı hatırlanmalıdır. ${ }^{23}$ Zihnin uykudaki etkilenimleri edilgin bir işlerliğe işaret eder; bu işlerlik Ben'e potansiyel olarak ait bilinçli yaşantıların Ben’in etkin bir konum almadığ yönelim taşımadığı ve dünyaya kayıtsız kaldığı durumlarda bile mevcut olduğunun bir kanıtıdır. Dolayısıyla zihnin uykudayken uyanmaya hazır olması askıya alınmış bir Ben'e ait ve örtülü halde kalan bilinçli bir yaşantıdır. ${ }^{24}$

William James’ten beri kullanılan bir tabirle her bireysel bilinç bir bilinç akışından meydana gelir. Koma ve genel anestezi hariç bilinç akışında beliren hiçbir sözüm ona kesinti (örneğin rüyasız uyku) bilincin zamansal birliğini bölüp iki bağımsız parça haline getiremez. Nitekim uyku ve uyanıklık aynı bilinç akışına ait safhalardır ve her bireysel bilinç bu safhaların arasındaki sürekliliği yakalayabilmesi sayesinde öbür bilinçlerden özce ayrılır. Locke’un sandığının aksine, bilinç akışının sürekliliği iki uyanıklık periyodunun birbirlerine kaldıkları yerden ve sanki hiç uykuya dalınmamış gibi bağlanmasıyla kurulmaz. Zira bilinç akışının sürekliliği sadece uyanıkken değil, uyku boyunca da kendini kurmaya devam eder. İşte bu sebeple, uyandığımda daima ne kadar uyuduğuma dair bulanık bir hisse sahibimdir. ${ }^{25}$

19 Buna itiraz olarak bir taşın da etkilendiği söylenemez mi? Bu yazı bağlamında etkilenimden nedensel-nesnel bir olayı değil, psişik-öznel bir olayı anladığımızdan ötürü, taşın etkilendiğini panpsişist bir önkabul taşımaksızın savunmak imkansızdır.

20 Maurice Merleau-Ponty, Phénoménologie de la perception, Paris: Gallimard, 1945, 328.

21 Jan Linchoten, "On Falling Asleep”, Phenomenological Psychology. Dutch School, ed. J. Kockelmans, Dordrecht: Martinus Nijhoff, 1987, 89.

22 Dan Zahavi, “Sleep, Self-awareness and Dissociation”, Alter. Revue de Phénoménologie, No:5, 1997, 141.

23 Edmund Husserl, Erfahrung und Urteil. Untersuchung zur Genealogie der Logik, ed. Ludwig Landgrebe, Hamburg: Claassen \& Goverts, 1948, 83.

24 Jan Linchoten, “On Falling Asleep”, a.g.e., 110.

25 Dan Zahavi, "Sleep, Self-awareness and Dissociation”, a.g.e., 141. 


\section{Husserl'de Uyku}

Deneyimlediklerimiz sadece dikkatimizi çeken, ilgimizi uyandıran şeylerden ibaret değildir. Dikkat çekmediği, ilgi uyandırmadığı halde deneyime giren ve sırf bu sayede sonraki bir deneyimde dikkat çekme ve ilgi uyandırma ihtimallerini saklı tutan pek çok şeyin de bilincindeyizdir. Tıpkı Leibniz gibi zihnin uyanıkken dahi dikkatimizi çekmeyen şeyler karsısında kısmi bir uyku durumu içinde olduğu söylenebilir. Fakat şu şartla: Bu mecazi anlamdaki uyku dikkatimizi çeken nesne karşısındaki uyanıklığımızın arka planını oluşturan zımni bir bilinçliliğe karşılık gelmelidir mutlaka.

Asıl anlamı dışında uykuya mecazi bir anlam vermek konusunda Husserl Leibniz'i izler. ${ }^{26}$ Husserl'e göre "alıcı" (rezeptiv) deneyimde bir "etkilenim" (Affektion) yaşandığında o etkilenime yanıt veren bilinç bir Ben'in yerine getirdiği “edim” yapısı taşır. Ben etkilenimin bilincine kayıtsız kalmadığı, etkilenimce yönlendirildiği ölçüde, bilinç onu etkileyen bir nesneye yönelir ve bu nesneyi temalaştırır. ${ }^{27}$ Ben dikkat yöneltip temalaştırdığı nesneyle meşgul durumda etkin ve uyanık bir hayat yaşarken, bu nesne bilincin ön planına yerleşir. Farkında olmayı sürdürdüğümüz tüm öbür nesneler ise bilincin arka planına kayıp uykuya dalar. Öte yandan, bu kısmi uyku süresince arka planın edilgin bilincine karşılık gelen dikkat etmediğimiz nesneler her an tekrar bizi etkileyip kendilerine çekerek onlara yönelik etkin bir bilinci uyandırabilir; bu etkin bilinç bir Ben'in ifa ettiği "yönleniş" (Zuwendung) biçiminde ortaya çıkar. ${ }^{28}$

Denebilir ki ön planın etkin ve belirtik bilinci, bağrında Ben'in hayat sürdüğü uyanık ve tematik bir bilinçken, arka planın edilgin ve örtük bilinci Ben’in hiçbir suretle katılmadığ uykudaki ve gayri-tematik bir bilinçtir. ${ }^{29}$ Fakat bu iki tür bilinç birbirlerine dönüşebilir. Örneğin, bilincin ön planı ile arka planı arasında zamansal mesafe bulunması koşuluna bağlı olan geçmişin hatırlanması olayını ele alalım. Birkaç gün önce işittiğimiz bir melodiyi veya eski bir arkadaşımızın adını hatırlamaya uğraşırken, hem bir bakıma ne aradığımızı biliriz hem de aranılan şey bizi onu her koşulda aramaya mecbur edecek denli erimimizin dışında kalır. Hatırlamayı başardığımızda ise melodinin ve adın bilinci hafızamızda tortulaştığı yerden silkinip canlanır, adeta uykusundan uyanır. Onlara yönelik bilincimiz tekrar uyanır uyanmaz melodi ve ad dikkatimizin merkezine oturur. Hafızada tortulaşmış halde uyanmayı bekleyen geçmişteki melodinin ve adın uykudaki örtük bilinci "bilinçdışı" bir karakter taşısa da tamamen bilinçsiz değildir; zira tekrar uyanık ve belirtik hale gelebilir. Bu demektir ki geçmişin bilincinin uyanması (Weckung) olarak hatırlama "bilinçdışı" biçimde geçmişte uyuyan melodinin ve adın bizi hala etkileme gücü taşımasından ötürü mümkün olur. ${ }^{30}$

26 Edmund Husserl, Späte Texte über Zeitkonstitution (1929-1934): Die C-Manuskripte, ed. Dieter Lohmar, Dordrecht: Kluwer, 2006, 42.

27 Edmund Husserl, Analysen zur passiven Synthesis. Aus Vorlesungs- und Forschungsmanuskripten (1918-1826), ed. Margot Fleischer, Den Haag: Martinus Nijhoff, 1966, 84.

28 Edmund Husserl, Aktive Synthesen: Aus der Vorlesung, "Transzendentale Logik“1920/21. Ergänzungsband zu „Analysen zur passiven Synthesis", ed. Roland Breeur, Dordrecht: Kluwer, Dordrecht, 2000, 4.

29 Bununla birlikte, Husserl'in dikkat ile uyanıklı̆ı birbirine eşitlemekten sakındığını hatıllatalım. Uyanık olmak bilincin bir nesneye dikkat yöneltmesinin önşartı olduğundan dikkati önceler. Bkz. Nicolas de Warren, "The Inner Night: Towards A Phenomenology of (Dreamless) Sleep", On Time. New Contributions to the Husserlian Phenomenology of Time, ed. Dieter Lohmar \&Ichiro Yamaguchi, Dordrecht: Springer, 2010, 285.

30 Edmund Husserl, Analysen zur passiven Synthesis. Aus Vorlesungs- und Forschungsmanuskripten (1918-1826), a.g.e., 179. 
Deneyimlerin peş peşe gelmesi tek başına bu peş peşeliğin deneyimini temin etmez. Zamansal deneyimin bu iki işlevi beraberce yerine getirebilmesi için her şimdi bilincinde az önce geçmiş olan şimdi bilincinin de modifikasyona uğrayarak "tutulması" gerekir. Buna Husserl'ci terminolojide "retansiyon" (Retention) denir. Bir müzik parçasını kesintili şimdilerin bir sıralanması olarak değil de akıcı bir süreklilik olarak deneyimlemeye imkân veren şey her şimdi bilincinde az önce geçmiş olan şimdiyi de kip değiştirmiş durumda algılamaya devam etmemizdir. Bir müzik parçasını dinlerken bilincin yerine getirdiği retansiyon işlemi o müzik parçasının zamansal birliğini deneyimlemenin önkoşuludur. Bu türden bir retansiyon "yakın retansiyon” diye adlandırılır. Öte yandan, geçmişin şimdiyle arasındaki zamansal mesafe genişlediğinde bu sefer başvurmamız gereken "uzak retansiyon" dur. ${ }^{31}$ Eski bir arkadaşın adı hafızamızda tortulaşıp bizim için uykuya dalsa bile bu adın onu tekrar hatırlamaya izin verecek şekilde zihnimizde tutulması böyle bir işleme örnektir. Geçmiş bizden ne kadar uzaksa, onu "tutmaktan" sorumlu retansiyon bilinci de o kadar güçsüz, belirsiz ve karanlıktır ki hatırlamayı zorlaştıran en başat etmen de budur. Bir anı zamansal arka planın derinliklerine gömüldüğünde bu anının bizi şimdide etkileme ihtimali azalır. Geçmiş bir deneyim bizden uzaklaşa uzaklaşa son kertede "bilinçdışına" (Unbewusst) kayar. Fakat bu bilinçdışı “ölü bir hiç" (totes Nichts) değil, aksine bilincin bir "sınır-kipidir"(Grenzmodus). ${ }^{32}$

Kısmi değil genel bir karakter taşıyan gerçek uykuda ise hem zamansal hem de mekânsal anlamda ön plan (dikkat odağı) ile arka plan (dikkat edilmeyen çeper) arasındaki ayrım ortadan kalkar. ${ }^{33}$ Zira tıpkı Leibniz'de olduğu gibi dikkat artık hiçbir şeye yönelmez; "her şey arka plandır, her şey karanlıktır." ${ }^{34}$ Gelgelelim bilincin tamamen ortadan kalkması değil, sadece bir Ben'e ait etkin yönelimlerin askıya alınması demektir bu. Birtakım ilgilere (Interessen) sahip etkin Ben Husserl'e göre bir "sınır-durum" (Limesfall) olan rüyasız uykuda tümüyle edilginleşip ilgilerinin neredeyse tamamından muaf hale gelir. ${ }^{35}$ Neredeyse dedik çünkü daha önce verdiğimiz örnekler arasında yer alan yalnızca bebeğinin sesiyle uyanabilen anne ve buna benzer istisnai durumlar uykuda ilgilerimizden mutlak biçimde yoksun olduğumuz varsayımını çürütür gibi durur. Zihin uykuda asgari düzeyde işlese de edim-yönelimselliğini kaybeder, "bir şeyin bilinci” olmaya ara verir. Kendisini cılız bir yeğinlikle etkileyen bir dışarıya, uyurken hassasiyetini kaybetmeyen duyu organları kanalıyla ona ulaşan hissî bir malzemeye sahipse de zihnin yaşadığı etkilenimler etkin bir Ben'in faili olduğu yönelimleri uykusundan uyandırmaya yetmeyecek denli kuvvetsizdir. Nitekim yatakta uykuya dalarken görsel ve dokunsal içerikler boğuklaşır, duyum akışı tekdüzeleşir. ${ }^{36}$

Dünyayı temsil etmeksizin ondan en aşağı derecede etkilenmeyi sürdüren bulanık uyku bilinci kesintisiz bir akış halindedir. Yeterince farklılaşmış değilse bile etkilenimin hiçbir suretle

31 a.g.e., 288.

32 Edmund Husserl, Erfahrung und Urteil. Untersuchung zur Genealogie der Logik, a.g.e., 336.

33 Hanne Jacobs, "I Am Awake: Husserlian Reflections on Attention and Wakefulness", Alter. Revue de phénoménologie, No: 18, 2010, 194.

34 Edmund Husserl, Ms F III 1/5a.

35 Edmund Husserl, Grenzprobleme der Phänomenologie. Analysen des Unbewusstseins und der Instinkte. Metaphysik. Späte Ethik. Texte Aus dem Nachtlass (1908-1937), Dordrecht: Springer, 2013, 8; Bkz. Edmund Husserl, Die Lebenswelt. Auslegungen der vorgegebenen Welt und ihrer Konstitution. Texte aus em Nachlass (1916-1937), ed. Rochus Sowa, Dordrecht: Springer, 2008, 591. 
söz konusu olmadığı bir durumda bulunmaz kesinlikle. Etkilenimin hiç olmaması bilinç için uykudan tekrar uyanmaya muktedir olmamak, yani koma ya da daha da kötüsü ölüm demektir. Halbuki uykunun karanlık bilinçliliğinde aslında hiçbir nesnenin bilinci olmayan içkin bir zamanı doldururuz. ${ }^{37} \mathrm{Bu}$ karanlıktan çıkıp tekrar uyanabilmemiz ve böylelikle etkin zihin faaliyetlerinin faili bir Ben olabilmemiz için bir farkın öne çıkıp kendini duyurmasına ihtiyaç vardır. Eğer herhangi bir fark bilincimizde öne çıkmışsa bunun nedeni bu farkın bizi onu duyumsayamadığımız zamana nispeten daha kuvvetlice etkilemiş olmasıdır. Etkilenmenin kuvvet derecesindeki bu artış ise uykudan uyanmamızı tetikler. Her “öne çıkma” (Abgehobenheit) özneye ait yaşamın bir modifikasyonudur. ${ }^{38}$ Aynı şekilde, uykuya dalarken fark edilebilir olan bütün etkilenimlerin kuvveti gitgide azalır ve bu azalış belirtik bir bilinçten örtük bir bilince geçişe işaret eder.

\section{Sonuç}

Uyanıkken uyanık olduğumuzun bilincinde olduğumuz halde, uyurken asla uyuduğumuzun bilincinde değilizdir. Zira kendisi itibarıyla uykunun bilincine varmak için çoktan uyanmış olmamız ve refleksiyon yardımıyla geride bıraktığımız uykuyu düşüncemize konu etmemiz lazım gelir. Gelgelelim bu demek değildir ki uyku refleksiyon-öncesi, cılız ve örtük bir bilinçlilikten yoksundur. Uykuda refleksiyon yoluyla kendimizin bilincinde olmadığımız, kendimizi nesneleştirmediğimiz aşikardır, ama gene de uykunun onu sadece benim başımdan geçen bir süreç kılan öznel bir karakteri vardır. Bu durum rüyasız uykuya deneyimin çeperinde beliren bir sınır-fenomen statüsü kazandırır. Nasıl ki bir başkasının acısını hissetmemiz imkansızsa, bir başkasının uykusunu uyumak ya da bir başkasının uykusundan uyanmak da elimizde değildir. Öte yandan, uykunun öznelliğinde nesnel bir dünyayla yüz yüze olan ve özne-nesne münasebetinden beslenen etkin bir öznellikten eser yoktur. Dünyayı temsil etmeksizin ondan etkilenen uykudaki özne bu etkilenimin kuvveti onu uyandırmaya yetmediğinden ötürü henüz dünyasız olsa da her an etkilenimin kuvvetindeki bir artışla uykusundan uyanarak dünyaya tekrar kavuşmaya muktedirdir.

Hakem Değerlendirmesi: Dış bağımsız.

Çıkar Çatışması: Yazar çkar çatış̧ması bildirmemiștir.

Finansal Destek: Yazar bu çalışma için finansal destek almadığını beyan etmiştir.

Peer-review: Externally peer-reviewed.

Conflict of Interest: The author has no conflict of interest to declare.

Grant Support: The author declared that this study has received no financial support.

37 Edmund Husserl Zur Phänomenologie der Intersubjektivität: Zweiter Teil: 1921-1928, ed. Iso Kern, Den Haag: Martinus Nijhoff, 1973, 157; Bkz. Edmund Husserl, Grenzprobleme der Phänomenologie. Analysen des Unbewusstseins und der Instinkte. Metaphysik. Späte Ethik. Texte Aus dem Nachtlass (1908-1937), a.g.e., 6 ve 14.

38 Edmund Husserl, Analysen zur passiven Synthesis. Aus Vorlesungs- und Forschungsmanuskripten (1918-1826), a.g.e., 379-380. 


\section{Kaynaklar}

Aristoteles, Ruh Üzerine, çev. Ömer Aygün \& Y. Gurur Sev, İstanbul: Pinhan yayıncılık, 2018.

De Warren, Nicolas, “The Inner Night: Towards A Phenomenology of (Dreamless) Sleep”, On Time. New Contributions to the Husserlian Phenomenology of Time, ed. Dieter Lohmar \&Ichiro Yamaguchi, Dordrecht: Springer, 2010, 273-294.

Descartes, René, Méditations métaphysiques. Objections et réponses suivies de quatres lettres, Paris: Flammarion, 1992.

Husserl, Edmund, Zur Phänomenologie der Intersubjektivität: Zweiter Teil: 1921-1928, ed. Iso Kern, Den Haag: Martinus Nijhoff, 1973.

Husserl, Edmund, Aktive Synthesen: Aus der Vorlesung „Transzendentale Logik“ 1920/21. Ergänzungsband zu „Analysen zur passiven Synthesis“, ed. Roland Breeur,

Dordrecht: Kluwer, 2000.

Husserl, Edmund, Analysen zur passiven Synthesis. Aus Vorlesungs- und

Forschungsmanuskripten (1918-1826), ed. Margot Fleischer, Den Haag: Martinus Nijhoff, 1966.

Husserl, Edmund, Die Lebenswelt. Auslegungen der vorgegebenen Welt und ibrer Konstitution. Texte aus dem Nachlass (1916-1937), ed. Rochus Sowa, Dordrecht: Springer, 2008.

Husserl, Edmund, Erfahrung und Urteil. Untersuchung zur Genealogie der Logik, ed. Ludwig Landgrebe, Hamburg: Claassen \& Goverts, 1948.

Husserl, Edmund, Grenzprobleme der Phänomenologie. Analysen des Unbewusstseins und der Instinkte. Metaphysik. Späte Ethik. Texte Aus dem Nachtlass (1908-1937),

Dordrecht: Springer, 2013.

Husserl, Edmund, Ms. B II 2 (Yayımlanmamış elyazması)

Husserl, Edmund, Ms. F III 1 (Yayımlanmamış elyazması)

Husserl, Edmund, Späte Texte über Zeitkonstitution (1929-1934): Die C-Manuskripte, ed. Dieter Lohmar, Dordrecht: Kluwer, 2006.

Jacobs, Hanne, "I Am Awake: Husserlian Reflections on Attention and Wakefulness", Alter. Revue de phénoménologie, No: 18, 2010, 183-201.

Kant, Immanuel, Anthropologie in pragmatischer Hinsicht, Reclam, Stuttgart, 1983.

Leibniz, G.W., Nouveaux essais sur l'entendement humain, Flammarion, Paris, 1990.

Locke, John, An Essay concerning Human Understanding, ed. Roger Woolhouse, London:

Penguin Books, 2004.

Linchoten, Jan, “On Falling Asleep”, Phenomenological Psychology. Dutch School, ed. J. Kockelmans, Dordrecht: Martinus Nijhoff, 1987, 79-118.

Merleau-Ponty, Maurice, Phénoménologie de la perception, Paris: Gallimard, 1945.

Zahavi, Dan, "Sleep, Self-awareness and Dissociation”, Alter. Revue de Phénoménologie, No:5, 1997, 137-151. 